\title{
Tecnologias digitais, espetáculo e violência na escola: uma análise de "Urso Branco"
}

\author{
Digital technologies, spectacle and violence at school: \\ a "White Bear" analysis
}

Tecnologías digitales, espectáculo y violencia en la escuela: un análisis de "Urso Branco"

Ana LaRa CAsagrande

Aliana França Camargo Costa

TEREZINHA FERNANDES (iD.

\section{Resumo}

O presente artigo se propõe a analisar as práticas de violência mediadas por aparatos tecnológicos no ambiente escolar, a partir do episódio intitulado Urso Branco, parte da série Black Mirror, da Netflix. Nesse episódio, há uma narrativa que se desenvolve em meio a um contexto de sadismo coletivo acerca da punição da personagem central, registrado pelos aparelhos celulares. Partimos do pressuposto de que a relação com a câmera é fundamental para a compreensão do registro passivo da violência e seu compartilhamento em redes. A abordagem deste texto é qualitativa e tem como eixos de desenvolvimento: o cenário mediado pelas tecnologias digitais; episódios de violências escolares; discussão sobre violência e conflito; o papel da escola e dos letramentos digitais em uma perspectiva social e abordagem crítica na educação. Notase que as práticas sociais, interfaceadas por produções e compartilhamentos de mensagens transmidiáticas, circulam fugaz e velozmente pela rede, o que demanda reflexão sobre as práticas de ensino docente, o papel da escola e a aprendizagem com

\footnotetext{
* Universidade Federal de Mato Grosso (UFMT), Cuiabá, MT, Brasil. Doutora em Educação, e-mail: analaracg@gmail.com

* Universidade Federal de Mato Grosso (UFMT), Cuiabá, MT, Brasil. Mestre em Estudos de Cultura Contemporânea, e-mail: alianacamargo@gmail.com

* Universidade Federal de Mato Grosso (UFMT), Cuiabá, MT, Brasil. Doutora em Educação, e-mail: terezinhaufmt@gmail.com
} 
o uso de tecnologias digitais, na ótica da repulsa às ocorrências de violência escolar, que infringem os direitos humanos, sociais e de acesso ao conhecimento de outrem.

Palavras-chave: Tecnologias Digitais. Câmera. Escola. Violência. Letramentos.

\begin{abstract}
This article proposes to analyze the violence practices registered by technological devices in the school environment, from the episode White Bear, part of the Black Mirror series, from Netflix. In it, there is a narrative that unfolds in a context of collective sadism about the punishment of the central character, recorded by cell phones. We start from the assumption that the relationship with the camera is essential for understanding the passive record of violence and it's sharing in networks. The approach of this text is qualitative and has as axes of development: the scenario mediated by digital technologies; episodes of school violence; discussion on violence and conflict; the role of school and digital literacy in a social perspective and critical approach in education. It is noteworthy that social practices along with the productions and sharing of transmissive messages circulate rapidly through the network, which demands reflection on the teaching practices, the role of the school and the learning with the use of digital technologies, in the optics of the rejection of the occurrences of school violence, which violate human, social and access rights to the knowledge of others.
\end{abstract}

Keywords: Digital Technologies. Camera. School. Violence. Letters.

\title{
Resumen
}

El presente artículo se propone analizar las prácticas de violencia difundidas por aparatos tecnológicos en el ambiente escolar, a partir del episodio titulado Oso Branco, parte de la serie Black Mirror, de Netflix. En ese episodio, hay una narrativa que se desarrolla en medio de un contexto de sadismo colectivo acerca del castigo del personaje central, registrado por los aparatos celulares. Partimos de la premisa de que la relación con la cámara es fundamental para la comprensión del registro pasivo de la violencia y su compartir en redes. El enfoque de este texto es cualitativo y tiene como ejes de desarrollo: el escenario mediado por las tecnologías digitales; episodios de violencia escolar; discusión sobre violencia y conflicto; el papel de la escuela y de letras digitales en una perspectiva social y enfoque crítico en la educación. Se observa que las prácticas sociales vinculadas por producciones y compartimentos de mensajes transmisibles circulan fugaz y velozmente por la red, lo que demanda reflexión sobre las prácticas de enseñanza docente, el papel de la escuela y el aprendizaje con el uso de tecnologías digitales, en la óptica de la enseñanza repulsa a las ocurrencias de violencia escolar, que infringen los derechos humanos, sociales y de acceso al conocimiento de otros.

Palabras clave: Tecnologías Digitales. Cámara. Escuela. Violencia. Alfabetizaciones. 


\section{Introdução}

A educação atualmente tem se reconfigurado em função das mudanças pelas quais a sociedade passa, sendo que parte considerável delas advém da cultura digital, que instala novas estéticas, desencadeando novas percepções cognitivas no ser e estar no mundo. Coloca-se nesta balança a utilização cada vez mais crescente e disseminada das Tecnologias Digitais (TD). Tal realidade impõe desafios para profissionais da área de educação.

O objetivo deste artigo é pensar como narrativas enquadradas pela série Black Mirror podem ajudar a pensar a Cultura Digital e os modus operandi pelos quais professores e instituições podem repensar propostas e atos de currículo para a Educação como um todo.

A série Black Mirror, criada pelo britânico Charlie Brooker e composta por episódios independentes, retrata comportamentos sociais mediados pelas tecnologias digitais. Neste trabalho analisaremos, em especial, o episódio intitulado originalmente White Bear, Urso Branco, no qual Victoria Skillane, sentada em uma cadeira, acorda sem lembrar-se de quem é. Nesse vazio existencial, ela segue em busca de informações e durante o percurso de fuga é perseguida por caçadores, ao mesmo tempo em que se encontra com pessoas que gravam os seus passos, por meio de dispositivos móveis como o celular, sem, contudo, ajudá-la. Na verdade, são pessoas que se deleitam sadicamente com a cena desenvolvida no White Bear Justice Park, criado especialmente para puni-la de um crime que, supostamente, envolve pedofilia e estupro.

Atualmente, quais reflexões podem ser feitas a partir do entendimento de que a escola é palco de punição, de violência e de estigma como configurado no episódio Urso Branco da série Black Mirror? De que forma as imagens captadas pelos celulares estão auxiliando nas formas de punir? Este está sendo utilizado para satisfazer um sadismo naturalizado de espetacularização? Os relacionamentos estão cada vez mais perenes no espaço escolar?

Abramovay e Rua (2002) trazem dados de um estudo que envolveu a aplicação de questionários estruturados a alunos, professores e pais de alunos em treze capitais 
brasileiras ${ }^{1}$, de estabelecimentos públicos e privados, dedicados ao Ensino Fundamental e Médio, nos turnos diurno e noturno, evidenciando vários tipos de violência nos estados investigados. Dentre a violência contra a pessoa estão: as ameaças, mais frequentemente mencionadas pelos estudantes de São Paulo e do Distrito Federal (40\%) e menos pelos de Belém (21\%); as brigas, os dados indicam a prevalência, entre os alunos, de um padrão de comportamento que descarta o recurso da autoridade policial ou a ajuda familiar para resolver episódios de violência praticados em grupo; e, as armas de fogo, os dados da pesquisa indicam que elas representam pequena fatia das armas encontradas nas escolas, encontram-se predominantemente as chamadas armas brancas e outras como correntes, cacetes e porretes: “os diretores e o corpo técnico-pedagógico relatam que é habitual encontrar essas armas com os alunos. Para alguns pais, é normal que os jovens portem armas brancas para se defender" (p. 54).

Com relação à violência contra a propriedade nas escolas, as autoras (ABRAMOVAY e RUA, 2002) levantaram a incidência de: roubos e furtos, de carros e objetos pessoais no ambiente da escola; dilapidação do espaço e do equipamento escolar, sem o furto de bens, que surge como ato de reação social contra a escola: “atos de pichação, depredação de muros, janelas, paredes e destruição de equipamentos, acompanhados de furtos, apresentam-se como formas de vandalismo mais comuns apontadas nas diversas categorias de entrevistados" (ABRAMOVAY e RUA, 2002, p. 60).

Para pensar nessas questões a partir do episódio Urso Branco, em conexão com vídeos gravados via celulares em escolas brasileiras, disponíveis para acesso na mídia social Youtube, refletiremos sobre a violência dentro dos espaços educativos e também o que a cultura digital traz enquanto mudanças na sociedade.

Pensadores, como Santaella (2013) e Castells (2015), ajudam a refletir sobre esse tempo em que novas estéticas instalam um nó na compreensão do que a cultura digital possibilita. Walter Benjamin (2014) nos auxilia a pensar as potencialidades que a câmera de celular possibilita no espaço social. Debarbieux (2002), Velho e Alvito

\footnotetext{
${ }^{1}$ Manaus, Belém, Fortaleza, Recife, Maceió, Salvador, Goiânia, Cuiabá, Vitória, Rio de Janeiro, São Paulo, Porto Alegre e Florianópolis.
} 
(2000) e Zaluar e Leal (2001) darão suporte à análise e às reflexões acerca da violência, suas manifestações sociais e no ambiente escolar. Dostoiévski (1866), por sua vez, ajuda a pensar, por meio de Crime e Castigo, a nova conjuntura de condenação massiva que se tornou a vida através dos cabos de fibra ótica e a questão do arrependimento do criminoso em meio a esse processo. Em sua narrativa, o autor nos conduz à culpa do protagonista sobre os assassinatos que cometeu a golpes de machado. Na Sibéria, o personagem central passa por uma espécie de reabilitação moral. Com Street (2014), é possível discutir os usos e os consumos de tecnologias digitais como práticas sociais, pelo viés dos letramentos, em uma perspectiva social, buscando o diálogo com uma abordagem mais crítica.

Por fim, apresentaremos caminhos possíveis para o cenário educacional desenhado pelo artigo, refletindo sobre os modos de ser e estar no mundo, mediado por tecnologias digitais, em que os campos éticos e estéticos devem ser constantemente debatidos.

\section{Para compreender o cenário da comunicação na cultura digital}

A Cultura digital instaura o conceito da ubiquidade como forma de estar lá e cá ao mesmo tempo. Dentro dessa configuração, o leitor ${ }^{2}$ passou a incorporar o adjetivo ubíquo, principalmente a partir dos anos 2000, com o boom dos computadores domésticos, no caso do Brasil. De acordo com Santaella (2013, p. 20), a característica desse leitor é a sua prontidão cognitiva, que se orienta e reorienta em nós e nexos multimídias, mesmo diante de tamanha informação, não perde o controle da sua presença onde está fixado.

Se o leitor movente inaugura formas não lineares de observar o mundo, o imersivo estabelece maneiras multilineares de olhar o mundo, e do cruzamento desses dois leitores emerge o leitor ubíquo. Diante disso, o sistema cognitivo dos leitores

\footnotetext{
${ }^{2}$ As raízes do leitor ubíquo se encontram no seu contexto histórico e reúne três tipos de leitores como explica Santaella (2013): contemplativos, moventes e imersivos. O contemplativo é aquele que se demora em refletir a informação, é fruto do renascimento, do livro impresso; o movente tem estreita ligação com o crescimento acelerado das grandes cidades.
} 
sociais se amplia com a chegada das tecnologias digitais. Artefatos culturais importantes para entender o momento pelo qual a cultura contemporânea passa é a utilização dos dispositivos móveis — os celulares.

Cada vez mais acessíveis, revolucionado por Steve Jobs com a tela touch screen, o toque com o dedo indicador confere poder a seu usuário. É um aparelho mágico capaz de transportar os espectadores da tela para lugares longínquos, sem que para isso seja preciso sair do lugar. Pequeno e portátil computador de mão, o celular permite uma comunicação multimodal, ajustado ao sistema de comunicação ubíquo, cuja fluidez suspende o tempo da reflexão. Tudo é feito de forma fluida, e se a usabilidade permite navegar no espaço de forma fácil, com dispositivo que tira foto, grava vídeo, interage com jogos, músicas, o usuário "toma a pílula" do piloto automático e se transporta para a Matrix existencial. Nesse sentido, estar conectado por meio do celular é pertencer a um universo que exige a participação virtual nos espaços fluidos da rede.

No cenário em que crianças, jovens e adultos pertencem à cultura digital, por nascimento ou adesão, os desafios para a educação são da ordem de buscar uma nova compreensão da cultura que está sendo remodelada. E se o campo da sala de aula está fixado nos trilhos da tradição, os estudantes que dela fazem parte vivem outra lógica, situada na cultura digital, distinta da educação tradicional.

$\mathrm{Na}$ perspectiva da aprendizagem, o leitor ubíquo, como explica Santaella (2013), requer flexibilidade, instantaneidade e novas expectativas de liberdade. De forma que a autoridade em sala de aula será trocada pela horizontalidade nas relações; se antes, professores, pais, coordenadores detinham a verticalidade na relação com os estudantes, conferindo um ar de domínio dos primeiros sobre os estudantes, essa relação é quebrada, configurando um mal-estar social e prevalecendo aspectos mais espontâneos, perenes, e até mesmo caóticos nos relacionamentos. Se antes a escola e a família eram as duas instituições encarregadas da tarefa de guardar o futuro dos mais novos (AQUINO, 2007, p. 66), agora, o choque das gerações ou a visão de que a escola não faz sentido provoca uma crise em que o desrespeito, a insubordinação, o revanchismo das gerações mais jovens com pais, professores e quem ocupa os postos pedagógicos, provoca um saldo negativo para a educação. 
A natureza dessa outra lógica de estar no mundo, encontra no poder da informação e na construção individual do conhecimento o caminho para trilhar um novo espaço. Diante disso, o professor passa a ser o mediador do conhecimento no processo de aprendizagem.

A nova ecologia da comunicação proporcionará a crianças e jovens uma poderosa forma de falar com o/no mundo. Cada um com seu computador de mão detém o poder da comunicação, entendendo, com Castells (2015), que o poder é o processo mais fundamental na sociedade, pois ela está incrustada nas relações entre as pessoas; e quem detém o poder, principalmente, de saber comunicar-se é capaz de influenciar outros atores sociais.

Sendo a internet o tecido que compõe a vida social nesta sociedade, a rede permite uma forma de comunicação de todos com todos, promovendo a autocomunicação de massa. Quando existe a possibilidade da informação ser autogerada e autosselecionada, cada um torna-se emissor e receptor ao mesmo tempo. Sendo produtor de conteúdos, o sujeito promove práticas diversificadas de comunicação. Logo, as variedades de significados são construídas na mente das pessoas. Esses significados têm tamanho poder que estão na ordem de determinar a ação e, conforme caracterizado por Castells (2015), passam a ser fonte de poder social por moldar a mente humana.

$\mathrm{Na}$ sociedade que se forma a partir das redes de comunicação, duas dimensões são importantes: a de base tecnológica e a cultural. A primeira reordena toda a nossa comunicação, a partir dos computadores digitalizados e da utilização dos softwares; na dimensão cultural existe tensão entre as identidades locais e o cosmopolitismo (cultura global). Se pensarmos nessas duas configurações, entenderemos que a cultura se move muito mais rápido do que antes. Questões como instantaneidade, presenteísmo, dissolução do tempo e espaço mudam as estéticas pelas quais vamos abordar nesta próxima seção, na qual relacionamos o episódio Urso Branco com recortes de violência evidenciados nos vídeos escolhidos para a reflexão neste texto. 


\section{Urso branco e a tela da escola}

O título da série Black Mirror, em português: espelho negro, evidencia que somos atravessados pelas tecnologias digitais em que a tela é escura, somos rodeados por ela, seja pela televisão, pelos dispositivos móveis a exemplo dos smartphones ou tablets. Essa tela é uma espécie de alucinógeno, capaz de fazer com que as relações interpessoais sejam condicionadas a um comportamento com traços de desumanidade.

No Dossiê Superinteressante (2018), dedicado à análise de alguns episódios da série, afirma-se, como curiosidade, que o roteiro original do episódio Urso Branco, do qual tratamos neste texto, foi alterado, já que inicialmente não previa a punição reiterada de Victoria e a narrativa terminaria com uma crucificação pública. No entanto, ao visitar a base aérea que serviria de locação e observar as cercas por todos os lados, "Brooker teve a ideia de criar um parque temático" (DOSSIÊE SUPERINTERESSANTE, 2018, p. 28), dedicado ao sadismo evidenciado no episódio.

Urso Branco começa com enquadramento no rosto de Victoria num ambiente escuro de um quarto. No momento em que o personagem acorda em estado de amnésia, se levanta de uma cadeira e vê na tela da televisão um símbolo, logo em seguida ela olha para um espelho, neste momento há o confronto entre o eu, quem é esse eu. Ao descer a escada da casa, ela encontra a foto de uma criança, e várias outras fotos emolduradas, sinalizando quem pode ser Victoria. A confusão psíquica da protagonista faz com que ela busque ajuda.

Ao sair da casa, o espaço gélido da rua passa a ser um caminho para entender quem é a mulher do espelho. No entanto, ela vê em muitas janelas pessoas com celulares na mão, neste caso o artefato cultural se torna uma arma para desnudar o comportamento de Victoria. Logo aparece um carro azul e um homem trajando um casaco vermelho sai do seu interior com uma espingarda na mão. Essa seria a segunda arma, mais letal e mais aniquiladora que a primeira. Começa aí uma corrida em que Victoria vai descobrir, no final dela, que tudo é armado para que ela seja a atriz principal em um parque onde as pessoas pagam para ver a sua punição/castigo, numa repetição sem perspectiva de fim. Pensando com Gomes, Pereira e Souza (2017, p. 
30), "o episódio nos dirige à estrutura do mito e da culpa que aponta para a lógica do neurótico naquilo que ela pode promover de repetição da punição e do castigo".

Questões como ética da tortura, o divertimento através da espetacularização da violência, vários juízes para imputar a liberdade de Victoria, emergem no momento em que se assiste às cenas. Teriam as pessoas que filmam o desespero de Victoria e os responsáveis pelo White Bear Justice Park, um tipo de neurose coletiva quando se utilizam do espetáculo da punição?

Alguns elementos chamam a atenção no episódio: o palco montado para que a protagonista fique no centro da inquisição, num espaço que é o mais escuro do episódio, com três telões, pessoas que tiram foto na plateia e ameaçam a personagem central, nos direciona para uma surpresa - a de que Victoria participou do homicídio da garotinha da foto, foi conivente e utilizou o celular para gravar o crime.

A realidade é que o nosso cérebro, quando recebe esse elemento surpresa, é afetado duplamente pelas emoções, que são percebidas como sentimentos; as reações aos eventos do filme se processam de forma interna e no inconsciente, o que nos leva a tomar a decisão em como nos posicionar diante de tudo que vimos. O nosso código moral, quando não afetado pela neurose, regula o nosso comportamento, a partir disso, somos levados ao seguinte questionamento: de protagonista mocinha a antagonista conivente com um ato criminoso, ela merece a punição? Qual tipo de punição?

Em outra cena, Victoria está numa espécie de carro, similar ao carro utilizado pelos papas em aparições públicas, informalmente chamado Papa móvel, a luz interna representa o camarim do espetáculo, ela está em uma cadeira de braço, como se já estivesse sentenciada à cadeira elétrica, não há para onde correr, o linchamento está posto e, pelo calendário mostrado em cena, ele é cíclico.

Chamamos a atenção, ainda, para a sequência na parte final em que o diretor do parque fornece instruções e recomendações aos frequentadores, dentre elas algumas crianças, que pagam para assistir ao castigo. As regras se aplicam em como as pessoas devem portar-se na construção da punição. A primeira delas é não conversar para que a personagem tenha a impressão de que o público está 
hipnotizado; a segunda regra é não chegar muito perto de Victoria, por ser perigosa. Por último, a regra é:

aproveitem! Essa é provavelmente a regra mais importante de todas. Tirem muitas fotos, corram pelo meio da floresta, mas sempre com segurança, nós vamos ficar de olho em vocês para garantir que estão bem. Vamos lá aproveitem e vamos fazer esse show acontecer! (NETFLIX, 2013).

Diante do infinito retorno que se torna o martírio da vida de Victoria, que inclusive pede para que a matem logo quando se dá conta do looping torturante ao qual é submetida, o questionamento é: o show deve continuar?

O livro A obra de arte na época de sua reprodutibilidade técnica, escrito entre 1935 e 1936 pelo alemão Walter Benjamin (2014), torna-se atual para pensar nessas manifestações contemporâneas. Benjamin (2014) fala sobre a câmera fotográfica e destaca a função do operador de câmera. Trazendo para a atualidade, todos nós somos potenciais operadores de câmera quando empunhamos um celular. O autor traz dois comparativos para exemplificar a questão: a diferenciação entre o mago e o cirurgião. O primeiro é o mesmo que o pintor, ele preserva a distância natural entre ele e aquele que é tratado, "ele diminui um pouco — por força de sua mão imposta —, e a aumenta muito — por força de sua autoridade” (BENJAMIN, 2014, p. 87). Já o cirurgião, assim como o operador de câmera, "diminui muito a distância em relação àquele que é tratado — na medida em que penetra em seu interior —, e a amplia só um pouco - por meio da cautela com a qual sua mão se move sob os órgãos” (p. 89). O operador é, por excelência, o instrumento que irá penetrar profundamente no "tecido da realidade dada".

A imagem proporcionada pelo pintor é total, a do operador de câmera é multiplamente fragmentada, sendo que as partes irão se juntar de acordo com uma nova lei. Assim, a natureza que fala à câmera não é a mesma que fala aos olhos. No sentido que, num segundo momento, o homem entretece o olhar inconscientemente, "por meio dela tomamos, pela primeira vez, conhecimento do inconsciente óptico, tal como tomamos conhecimento do inconsciente pulsional pela psicanálise” (p. 99). O autor fala que há estreita relação entre esses dois inconscientes e que o aparato pode extrair da realidade, em parte considerável, aspectos que estão fora do campo normal das percepções sensoriais. 
É interessante esse posicionamento do inconsciente, já que o autor fala sobre as deformações e estereotipias, das metamorfoses e catástrofes que são enquadradas pela ótica do cinema, afetam também as psicoses, as alucinações e os sonhos: "E, assim, aqueles modos de proceder da câmera correspondem a muitos procedimentos graças aos quais a percepção coletiva pode se apropriar dos modos individuais de percepção do psicótico ou do sonhador” (BENJAMIN, 2014, p. 101).

Benjamin (2014) vislumbrou que o aparato emanciparia o homem, e que por meio dele sairia para um mundo de maior liberdade. Entretanto, considerou que a tecnicização, com suas perigosas tensões, poderia trazer também consequências para as grandes massas, que poderiam assumir o aparato com um caráter psicótico — "nos quais o desenvolvimento forçado de fantasias sádicas ou delírios masoquistas pode impedir o amadurecimento natural e perigoso destes nas massas” (p. 103). E postula que os enquadramentos grotescos que ameaçam a humanidade são resultantes das repressões que cada um carrega consigo.

A distopia em Urso Branco é a realidade de muitas escolas brasileiras, o episódio traz a questão ética de colocar ou não de lado o código moral, para que possa observar com certo sadismo o sofrimento do outro. De modo que o espetacular na condenação de Victoria refere-se à identificação de todos nós que convivemos em sociedade. O episódio permite que seja estabelecida relação com a realidade encontrada nas escolas: estudantes com seus aparatos tecnológicos registrando e divulgando a violência dentro do espaço escolar, projetando na tela das escolas a polêmica sobre as punições não convencionais.

A título de demonstração da realidade atual, recuperemos o episódio ocorrido em Rio das Ostras no Rio de Janeiro, em 18 de setembro de 2018, com o professor Thiago dos Santos Conceição ${ }^{3}$. No vídeo intitulado Professor é humilhado em Sala de Aula no estado do Rio de Janeiro, visualizado mais de um milhão de vezes na mídia social Youtube, que viralizou também nas redes sociais, o professor aparece como protagonista de uma cena de horror: pedindo ajuda enquanto alguns estudantes rasgam as avaliações escritas, depredam o patrimônio público e outros... filmam. Nas

\footnotetext{
${ }^{3}$ Este vídeo foi visualizado 1.083 .771 (um milhão oitenta e três mil e setecentos e setenta e uma) até o dia 25 de outubro. Está disponível em: https://www.youtube.com/watch?v=ny3pY_0QMoQ 
imagens, um dos adolescentes arremessa um objeto na direção do professor, enquanto ele escrevia na lousa.

A repercussão desse caso foi muito grande, de maneira que a mídia jornalística explorou a notícia em vários canais de comunicação, por exemplo, foi construída uma matéria no Fantástico, programa dominical da Rede Globo de televisão, exibido em 23 de setembro de $2018^{4}$, na qual a equipe vai à casa do professor, relata a trajetória do mesmo, seu sonho em seguir a carreira docente. O professor Thiago relata que na aula do vídeo viralizado: "Os alunos me receberam com palavras de baixo calão, xingamentos, agressões, eles debochavam, enquanto depredavam a escola. Um [teve] comeu a prova, eu nunca tinha visto, foi um pesadelo, nem em filme de terror eu vi aquilo. Eu achei que fosse morrer" (PORTAL G1, 2018).

$\mathrm{Na}$ construção dessa matéria televisiva, relata-se que o estudante que atirou um objeto no professor e comeu (literalmente) um pedaço da prova, postou um pedido de desculpas na internet. A equipe de reportagem visita a avó (descrição: "ele tem 16 anos e é criado pela avó”), isto é, salienta-se o papel dela 5 , que, em seu depoimento, relata: "É isso que eu falo para ele: não foi a educação que te dei não". Afirma-se na reportagem que o adolescente, arrependido, queria encontrar-se com o professor para pedir desculpas. O que efetivamente ocorre, promovido pela equipe e filmado, salvaguardando-se o rosto do adolescente, como determina o artigo 247 da Lei $n^{\circ}$ 8.069 de 13 de Julho de 1990, por tratar-se de menor de idade. No encerramento da matéria uma turma da escola presta homenagem ao professor vítima da violência.

Tanto o adolescente da escola do Rio de Janeiro, quanto Victoria em Urso Branco, pedem desculpas, verbalizam um arrependimento, o que permite uma analogia com a obra Crime e Castigo. Nela, Dostoiévski (1866) relata uma espécie de redenção via confissão do personagem principal, o jovem Rodion Raskolnikov, responsável pelo assassinato de uma velha agiota com um machado e de sua meia-irmã, que testemunhara o crime. O foco nos diálogos internos do personagem central permite

\footnotetext{
4 Disponível na íntegra em: https://g1.globo.com/fantastico/noticia/2018/09/23/conheca-ahistoria-de-professor-que-pediu-demissao-apos-ser-agredido-por-alunos.ghtml

${ }^{5}$ Criticamente, podemos analisar o fato de a reportagem ter enfatizado isso, como uma referência indireta à falta da figura paterna ou à configuração familiar peculiar como suposta explicação para o comportamento do adolescente.
} 
que pensemos no possível estado de delírios em que entra a pessoa que comete violência. Além disso, Rodion enfatiza, ao longo da obra, que não sente culpa, no entanto, as suas perturbações morais, que o impediram inclusive de "aproveitar-se" do roubo, apenas findam quando confessa o seu crime à polícia, incentivado por Sônia, por quem o personagem se apaixona. Sua pena foi a reclusão por oito anos na Sibéria: "O criminoso manteve firme, clara e exatamente a sua declaração, sem omitir nenhum pormenor nem atenuá-los a seu favor, sem falsear os fatos nem esquecer a menor circunstância" (p. 573).

Em outro vídeo de 1'33" intitulado Alunos brigam em sala de aula e professora continua dando aula como se nada tivesse acontecendo ${ }^{6}$, publicado em 21 de fevereiro de 2017, mostra a dimensão do problema enfrentado pelas escolas. No pouco tempo do vídeo, o que se vê é um clima desolador num cenário que deveria ser de boa convivência e aprendizado. Dois meninos, com idades por volta de 12 anos, estão dentro da sala de aula em uma cena de luta livre. A sequência de chutes e socos está sendo realizada inacreditavelmente durante a aula de português, a professora não para a sua aula e os outros colegas, que não aparecem no vídeo, continuam a soletrar as palavras no esforço de conjugar o verbo como se nada tivesse acontecendo: "eu namorei... ele namorou... nós namoramos..." dizem os estudantes sob a orientação da professora.

No vídeo, a sala se comporta como se o fato dos dois meninos se digladiarem bem à frente fosse algo banal e destituído de qualquer importância. Filmado com a câmera de celular na posição vertical, há um limite nas bordas e o que é possível ver é que a sala é escura e há apenas luz que entra através da porta. A primeira cena do vídeo tem início com os meninos no chão, aos 10 segundos de gravação, é possível ouvir um soco dado por um deles no outro, o que não afeta ninguém. A leitura da conjugação do verbo namorar no presente do indicativo continua; como compreender esse verbo transitivo direto cujo significado é "Esforçar-se para conseguir inspirar amor a alguém" (DICIONÁRIO MICHAELIS), quando no mundo concreto o que se mostra é agressão, raiva, ódio e covardia?

\footnotetext{
${ }^{6}$ Até o dia 25 de outubro de 2018, o vídeo contava com 555 visualizações. Este vídeo pode ser encontrado em outros canais. $O$ interpretado por nós se encontra disponível em: https://www.youtube.com/watch?v=sAp2b4q-AGo.
} 
Por um momento, a professora investe numa tentativa frustrada de apartar a briga, mas no segundo 16" um estudante diz: "tô filmando tia, licença tia, sai... sai... sai...", "tira a vassoura” grita outro atrás, "Bora ler tia, bora ler tia” fala um terceiro, querendo voltar à "quase normalidade" daquela que deveria ser uma aula. No chão, com os braços fazendo uma alavanca no pescoço do outro, um dos meninos da briga encara o operador da câmera e balbucia algo como desaprovando aquela gravação, possibilitando ver os rostos das crianças sem censura, logo, o menino vê-se impelido a continuar a briga para não perder a luta. Aos 45" segundos eles se levantam, se entreolham girando como para iniciar nova batalha, neste momento a professora poderia apartar, mas será que ela teria coragem? O que fundamenta a omissão da professora?

Aos 56" segundos, a luta inicia novamente e o som ao fundo se repete, paralelamente, a professora aponta no quadro a conjugação de outro verbo. "Essa é a briga" diz um dos estudantes com o uniforme azul que aparece na tela, e outro diz “primeiro round". Para o espectador a briga não acaba.

\section{O cenário escolar também se reconfigura com a hipérbole das personalidades midiatizadas}

No espaço da escola há uma leitura sobre os comportamentos, ideias, bem como consequências dessa conduta e qual o entendimento para a resolução dos conflitos e da violência nesse contexto. Assim, as tecnologias digitais permeiam o debate sobre o fenômeno da violência escolar porque participa recebendo o que chamamos aqui de hipérbole das personalidades midiatizadas, aquelas que resultam do exagero e estão em exposição nas mídias digitais. Isso implica no entendimento de que as pessoas tinham essas personalidades, e que as tecnologias como mediadoras possibilitam dar visibilidade, permitem que seja posta uma lente de contato via conexões e compartilhamentos.

A violência é inerente à sociedade, pois é construída socialmente, de modo que não deve ser considerada um fenômeno recente como muitos afirmam. O que pode dar essa impressão é a velocidade com a qual as informações chegam às pessoas em tempos de acesso à internet. Para compreendê-la de forma ampla, cabe elencar a 
interferência de vários fatores como exclusão social, condições econômicas e familiares, políticas públicas e relações de poder (DEBARBIEUX, 2002).

O conflito é entendido por Zaluar e Leal (2001) enquanto forma de sociabilidade, desenvolvido por meio da interação entre contrários. As autoras advertem que há confusão entre o termo conflito e violência, o que faz com que haja barreiras no entendimento adequado do fenômeno. O termo violência é visto como instrumento, envolvendo o uso de força física ou coação moral, e geralmente está associado a um estado social permanente e excessivo das classes menos abastadas, enquanto o conflito faz parte das relações humanas, visto que o consenso não é possível unanimemente, tampouco é permanente.

Nessa acepção, o conflito deve ser considerado um mecanismo de externalização dos posicionamentos divergentes, o que é diferente da violência. À medida que não se garante dentro da escola espaços para manifestação saudável dos posicionamentos, entendemos que a intenção de calar ou destruir o outro sujeito ganhe espaço. Durante o conflito, os sujeitos desenvolvem regras de conduta e meios de expressão dos seus interesses, instituindo a socialização e estabelecendo um limite para não chegar-se à violência. Portanto, o conflito auxilia na criação de normas, leis que se baseiam no respeito mútuo e ideias partilhadas (ZALUAR; LEAL, 2001).

A violência se caracterizaria, então, por manifestações extremas baseadas na destruição moral, psicológica ou física dos outros sujeitos e, portanto, está dissociada do processo de conflito. A violência intenta destruir de alguma maneira o adversário, impossibilitando a manutenção do conflito, devido à impossibilidade de existir força de uma das partes, que perde sua possibilidade de manifestação na inexistência de regras justas e partilhadas (ZALUAR; LEAL, 2001).

Especificamente sobre o caso do Brasil, Velho e Alvito (2000) consideram que a violência está atrelada ao não acesso aos bens culturais por grande parte da população, bem como o esvaziamento de conteúdos culturais. Kuenzer (1995) também reconhece a produção e apropriação do saber uma das mediações na relação de classe, a solução, para a autora, passa pela garantia do "acesso e permanência dos filhos da classe trabalhadora na escola, por meio de um projeto pedagógico que tome sua prática social como ponto de partida" (p. 195), já para o adulto propõe "que a 
escola se dê conta de que é preciso ultrapassar esse nível formal com a oferta de outras alternativas que tomem como ponto de partida o 'trabalhador concreto' com sua prática, seu saber, suas experiências de vida, suas necessidades” (p. 196).

Para a superação do cenário de violência, Abramovay e Rua (2002, p. 74) defendem a necessidade de promover a cultura da paz, por meio de uma escola que seja:

1. Lugar de encontro de diversidade cultural e habilitado para formas criativas de solidariedade. 2. Potencial estratégico para tecer relações com a comunidade, especialmente a família, tendo os pais como parceiros para tal fim. 3. Possibilidade de experimentar medidas de prevenção e de acompanhar tanto a população-foco como as experiências implementadas de políticas públicas. 4. Formação de valores e transmissão de conhecimentos, o que tem prosseguimento nos processos de interação não somente entre professores e alunos, mas também entre os próprios estudantes.

Para Martín-Barbero (2009), é necessário pensar nas possibilidades reais de apropriação social e cultural com o uso de tecnologias, em nível de política nacional e em nível do cotidiano das práticas e seus efeitos sobre a cultura, pois se tencionam, de um lado, o ativismo de produtores e, do outro, a mera passividade de consumidores, como vimos no episódio Urso Branco e nos vídeos citados neste texto.

Pensar práticas formativas de tais dispositivos, remete-nos à necessidade de reconfiguração de práticas cotidianas, conforme Certeau (1998, p. 41): “as maneiras de fazer constituem as mil práticas pelas quais os usuários se apropriam do espaço organizado pelas técnicas da produção sócio-cultural”. Ou seja, a escola deve preocupar-se com aquilo que o estudante (praticante cultural) "fabrica". Essa fabricação é uma produção, é aquilo que ele faz de maneira astuciosa, dispersa, ubíqua - estar conectado à rede e fazer uso da conexão a todo o momento, silenciosa, invisível, se faz notar pelas maneiras de empregar tais produtos culturais impostos por uma ordem dominante. Deste modo temos em jogo cultura, poder, discurso, criatividade e crítica, dentre outros aspectos que envolvem o ato de gravar e compartilhar algo na rede.

Compreender tais cenas contemporâneas e seus desdobramentos na educação requer deslocar a ênfase às mediações, as interações e aquilo que pode ser apropriado e produzido pelos sujeitos, como aponta Jenkins (2009), com a convergência de mídias e linguagens potencializa-se a inteligência coletiva, a cultura participativa e os 
letramentos midiáticos dos estudantes como a leitura, escrita, análise linguística, análise literária, edição, editoração e outros.

Ao levar em conta que tais práticas sociais são letramentos digitais que emergem com mais intensidade na cultura digital, conforme lembra Souza (2016), estão implicados os artefatos culturais, as interfaces, os gêneros e as linguagens digitais, e estas práticas se dão por processos dialógicos, de mediação e de interação entre os praticantes culturais em processos formativos. Na mesma direção, Street (2014) aponta para a perspectiva social dos letramentos e para uma abordagem crítica na educação, focalizando o seu caráter ideológico e múltiplo, em que as diversidades culturais sejam levadas em conta, o poder das instituições, a identidade dos sujeitos, a agência como espaço-lugar de formação e o discurso produzido e significado como mobilizador de aprendizagens.

Para pensar o cenário escolar de outro modo, na cultura digital, em que as relações são permeadas pela mediação do digital em rede, é necessário desnaturalizar a banalização e espetacularização que recobre os usos e consumos das mídias digitais, reforçam o controle, a vigilância e a punição e ferem questões éticas, de privacidade e de identidade, não retomando os velhos dilemas de dizer sim ou não, mas problematizá-los como produtos culturais.

\section{Considerações finais}

A análise feita a partir do episódio Urso Branco, da série Black Mirror, da Netflix, apontou para questões relacionadas ao uso de tecnologias digitais em rede e suas nuances e complexidades quando se trata de práticas na escola, que se desenvolvem a partir de situações cotidianas semelhantes, envolvendo o registro da violência e do conflito e o compartilhamento deliberado dessas produções na internet, colocando os sujeitos envolvidos em situação de exposição e vulnerabilidade social.

O cenário educacional mediado por tecnologias digitais requer da escola não apenas o papel de problematizar o uso de tais artefatos como base tecnológica e 
cultural importantes para o processo de comunicação, mas enquanto agência promotora de conhecimentos que tencionam estes usos e consumos levando em conta os saberes e identidades locais em diálogo com os conhecimentos globais e que por isso podem e devem ser produções e criações éticas, críticas e de alteridade.

Práticas sociais interfaceadas por produções e compartilhamentos de mensagens transmidiáticas circulam fugaz e velozmente pela rede e possibilitam a coautoria, a colaboração e o desenvolvimento de letramentos digitais na educação, em geral, e na escola, especificamente, isso aponta para a contribuição da análise feita neste texto, a partir das narrativas do episódio e dos vídeos para pensar os modos pelos quais os professores podem potencializar as suas práticas de ensino e aprendizagem com o uso de tecnologias digitais. Desse modo, é necessário colocar em debate a questão da violência escolar, analisando contextos, incidências e modos de legitimação, a fim de cogitar uma mudança do cenário posto quanto a essas ocorrências (registradas e postadas em rede) nas escolas brasileiras.

Dada a complexidade de discutir práticas de violência em espaços educativos, a relação destas com a cultura digital e suas implicações na sociedade contemporânea, tais temáticas permanecem como espaços abertos para estudos e novos arranjos com vistas a refletir sobre as necessidades e reconfigurações da educação nesse contexto.

\section{Referências}

ABRAMOVAY, M.; RUA, M. das G. Violências nas escolas. Brasília: UNESCO Brasil, Rede Pitágoras, Coordenação DST/AIDS do Ministério da Saúde, Secretaria de Estado dos Direitos Humanos do Ministério da Justiça, CNPq, Instituto Ayrton Senna, UNAIDS, Banco Mundial, USAID, Fundação Ford, CONSED, UNDIME, 2002.

AQUINO, J. G. Instantâneos da escola contemporânea. Campinas: Papirus, 2007. 128p.

BENJAMIN, W. A obra de arte na época de sua reprodutibilidade técnica. Trad. Francisco de Ambrosis Pinheiro Machado. 2. Reimpr. Porto Alegre, RS: Zouk, 2014.

CASTELLS, M. O poder da comunicaşão. Trad. Vera Lúcia Mello Joscelyne. 1. ed. São Paulo/Rio de Janeiro: Paz e Terra, 2015.

CERTEAU, M. A Invenção do Cotidiano: artes de fazer a invenção do cotidiano. Editora Vozes: Petrópolis, 1998.

DEBARBIEUX, E. Violência nas escolas: divergências sobre palavras e um desafio político In: DEBARBIEUX, E.; BLAYA, C. (Orgs.) Violência nas Escolas e Políticas Públicas. Brasília: UNESCO, p. 59-92, 2002. 
DOSSIÊ SUPERINTERESSANTE. Isso é muito Black Mirror. Editora Abril, 2018.

DOSTOIÉVSKI, F. M. Crime e castigo. Editora 34, 1866.

GOMES, P. H. R; PEREIRA, C. L; SOUZA, F. R. V. Identificação e Imagem: uma leitura psicanalítica do seriado Black Mirror. Revista Extensão em Ação, Fortaleza, v. 2, n. 14, jul./dez. 2017. Disponível em: <http://www.periodicos.ufc.br/extensaoemacao/article/viewFile/20310/71608>. Acesso em: 24 out. 2018.

JENKINS, H. Cultura da Convergência. 2 ed. São Paulo: Aleph, 2009.

KUENZER, A. Z. Pedagogia da fábrica: as relações de produção e a educação do trabalhador. 4 ed. rev. São Paulo: Cortez, 1995.

MARTÍ́N-BARBERO, J. Dos Meios às Mediaģões: comunicação, cultura e hegemonia. Tradução de Ronald Polito e Sérgio Alcides. 6. Ed. Rio de Janeiro: UFRJ, 2009.

MICHAELIS. Dicionário Brasileiro da Lingua Portuguesa. 2018. Disponível em: <https://michaelis.uol.com.br/moderno-portugues/busca/portugues-brasileiro/namorar/>. Acesso em: 13 de set. 2018.

PORTAL G1. Conbeça a história de professor que pediu demissão após ser agredido por alunos, set. 2018. Disponível em <https://g1.globo.com/fantastico/noticia/2018/09/23/conheca-a-historia-deprofessor-que-pediu-demissao-apos-ser-agredido-por-alunos.ghtml>. Acesso em: 30 de set. 2018.

SANTAELLA, L. Desafios da ubiquidade para a educação. Revista Ensino Superior Unicamp, Ed. Especial Novas mídias e o Ensino Superior, abr. 2013. Disponível em: $<$ https://www.revistaensinosuperior.gr.unicamp.br/edicoes/edicoes/ed09_abril2013/NMES_1.pd f>. Acesso em: 21 de ago. 2018.

SOUZA, T. F. M. de. Ondas em Ressonância: Letramentos Digitais de Estudantes na Universidade Aberta de Portugal. Tese (Doutorado em Educação) - Centro de Educação. Programa de Pósgraduação em Educação. Universidade Federal de Santa Catarina, 2016.

STREET, B. Letramentos Sociais: abordagens críticas do letramento no desenvolvimento, na etnografia e na educação. Trad. Marcos Bagno. São Paulo: Parábola Editorial, 2014.

VELHO, G.; ALVITO, M. Cidadania e violência. Rio de Janeiro: Editora FGV; Editora UFRJ, $2^{a}$ edição, 2000.

ZALUAR, A.; LEAL, M. C. Violência extra e intramuros. Revista Brasileira de Ciências Sociais, p. 16-45, 2001. 